\title{
HPTLC Analysis, Antioxidant and Antidiabetic activities of Ethanol Extract of Moss Fissidens grandiflora
}

\author{
HO VIET HIEU, V. B. TATIPAMULA ${ }^{1,2}$, K. N. KILLARI ${ }^{3,{ }^{*},}$ SREE TEJA KONERU ${ }^{4}$, NALLAPATY SRILAKSHMI ${ }^{4}$, \\ S. K. RANAJITH ${ }^{5}$
}

Department of Medical Microbiology and Parasitology, Faculty of Medicine, ${ }^{1}$ Institute of Research and Development, ${ }^{2}$ Faculty of Pharmacy, Duy Tan University, Da Nang 550000, Vietnam, ${ }^{3}$ Pharmaceutical Chemistry Department, AU College of Pharmaceutical Sciences, Visakhapatnam-530 003, ${ }^{4} \mathrm{~K}$ L College of Pharmacy, Koneru Lakshmaiah Education Foundation, Vaddeswaram, Guntur-522 502, 5Vignan College Of Pharmacy, Duvvada, Visakhapatnam-530 049, India

Killari et al.: Chemical and Biological Profile of $\boldsymbol{F}$. grandiflora

\begin{abstract}
The phytochemical composition, antioxidant and antidiabetic profile of ethanol extract of Fissidens grandiflora was investigated for the first time. The phytochemical analysis of Fissidens grandiflora confirmed the presence of flavonoids, phenolics, steroids and tannins. Additionally, Fissidens grandiflora contained a high amount of total flavonoids of $101.40 \pm 0.38 \mathrm{mg} \mathrm{Q} / \mathrm{g}$. The high-performance thin-layer chromatography analysis of Fissidens grandiflora identified 3 unknown components with different $R_{f}$ values and area percentage. Fissidens grandiflora showed better inhibition of superoxide free radicals, 2,2-diphenyl-1-picryl-hydrazyl-hydrate free radicals and ferric ions with $\mathrm{IC}_{50}$ values of 81.0, 85.0 and $92.6 \mu \mathrm{g} / \mathrm{ml}$, respectively. Additionally, Fissidens grandiflora depicted a prominent inhibitory profile against $\alpha$-glucosidase and pancreatic $\alpha$-amylase with $\mathrm{IC}_{50}$ values of 150.0 and $200.0 \mu \mathrm{g} / \mathrm{ml}$, respectively. To conclude, the proposed mechanism of action of moss Fissidens grandiflora could be by inhibiting free radicals and particularly digestive enzymes.
\end{abstract}

Key words: Antidiabetic, antioxidant, Fissidens grandiflora, moss, pancreatic $\alpha$-amylase, $\alpha$-glucosidase

Morphologically, bryophytes are a symbiosis of algae and pteridophytes with around 25000 species across the globe. Taxonomically, they are classified into liverworts, hornworts and mosses ${ }^{[1]}$. Mosses are the simplest-level plants that belong to the second-largest taxonomic group among bryophytes with 14000 species around the world ${ }^{[2]}$. Mosses survive on wet and humid places, and mostly grow on rocks, soil, woods and walls of a building ${ }^{[3]}$. Mosses are widely present in forest ecosystems and in the Northern Hemisphere ${ }^{[4]}$.

Natural sources play a prominent role in the origin of new biological agents that include antioxidants and antidiabetes, which examined to be effectual as well as safe alternative method in the therapy for diabetes mellitus, instead of synthetic molecules ${ }^{[5]}$. As a result, search to identify new bioactive molecules and their derivatives for treating diabetes has become an aspect of interest. According to recent research studies, several aquatic organisms including mosses ${ }^{[6]}$ were found to be a source of these bioactive molecules. Traditionally, tribes of North America utilized mosses for the

*Address for correspondence E-mail: kishorenaidu.killari@gmail.com management of convulsions, neurasthenia, pneumonia, scald, burns, tuberculosis, and others. In the folklore of China and India, extracts of mosses are well-known for antimicrobial activity and to treat anxiety, snake-bites, heart problems, tuberculosis, cancer, and diabetes ${ }^{[5,6]}$.

A long time ago, mosses were less considered for the identification of bioactive substances due to problems in identification ${ }^{[7]}$. However, in recent times, research attention to mosses chemical profile is increasing, as several biologically active components are identified from these due to their unique adaptations ${ }^{[8]}$. However, from a large number of mosses only a very few species have been studied. Additionally, the study of the chemical composition of mosses assists in knowing their metabolism ${ }^{[9]}$. This is an open access article distributed under the terms of the Creative
Commons Attribution-NonCommercial-ShareAlike 3.0 License, which
allows others to remix, tweak, and build upon the work non-commercially,
as long as the author is credited and the new creations are licensed under
the identical terms

Accepted 20 April 2020 Revised 24 March 2020

Received 04 December 2019 Indian J Pharm Sci 2020;82(3):449-455 
The major chemical constituents of mosses are carbohydrates, essential oils, fatty acids, lipids, flavonoids, cinnamic and benzoic acid derivatives, bibenzyl and benzyl derivatives, volatile oils, polyphenols, terpenoids, steroids and some nitrogencontaining aromatic compounds ${ }^{[10-12]}$. There are also reports that extracts of mosses help against a wide range of bacteria and fungi and also act as 15-lipoxygenase inhibitor, wound healing agents, sedatives, cytotoxic, antiHIV, antioxidant, antifeedant, antitumor and proapoptotic and nematocidal due to the presence of terpenoids and aromatic compounds ${ }^{[5,8,11-17]}$. Polytrichum moss species also present diuretic, antipyretic and antitodal activities and can be used to promote hair growth ${ }^{[9]}$. Moss Taxithelium nepalense has antioxidant and antidiabetic activities ${ }^{[18]}$.

Fissidens genus belonging to family Fissidentaeae with about 400 species worldwide, distributed mainly in humid, tropical and warm temperate regions. Particularly, moss Fissidens grandifolia reported in the flora of India, China, North and Central America, Africa, West Indies, Mexico and Europe ${ }^{[19]}$. Literature survey did not reveal any chemical and biological profiles of the genus Fissidens. Hence, to know the chemical profile of $F$. grandifolia, a phytochemical and chromatographic analysis of the ethanol extract (F. grandifolia) was carried out to correlate these to its biological profile. The purpose of the present research study was to analyse the chemical composition of F. grandifolia by means of phytochemical, highperformance thin-layer chromatography (HPTLC), total flavonoid and phenolic content and to monitor antioxidant and antidiabetic activities.

\section{MATERIALS AND METHODS}

HPTLC plates silica gel 60 F 254 was purchased from Merck Ltd. (Mumbai, India). 1,1-diphenyl-2picrylhydrazyl (DPPH) and intestinal acetone powders from rats were purchased from Sigma Aldrich (Mumbai, India). Amylase HR reagent was obtained from Pro Lab Marketing Pvt. Ltd. (New Delhi, India). All other chemicals used in this study are of analytical grade.

\section{Plant collection:}

Specimens of moss $F$. grandifolia were collected from tree barks near Coonoor, Nilagiri hills, Tamil Nadu, India

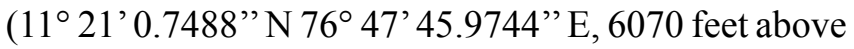
sea level) in August 2019. Authenticated specimens of $F$. grandifolia was deposited with an accession number LWG-36/VB-Orissa-2019 at Bryophyte Herbarium,
CSIR-National Botanical Research Institute (NBRI), Lucknow, India.

\section{Extraction and phytochemical analysis:}

The dried specimens of moss $F$. grandifolia (about $50 \mathrm{~g}$ ) was extracted thrice with ethanol and concentrated under reduced pressure to obtain ethanol extract of F. grandifolia as a dark greenish residue $(2 \mathrm{~g}, 4 \% \mathrm{w} / \mathrm{w})$, preserved at $4^{\circ}$ for further use. Phytochemical analysis ${ }^{[20]}$ was carried out on the extract of $F$. grandifolia using standard stratagems for the identification of chemical constituents.

\section{HPTLC analysis:}

HPTLC analysis ${ }^{[21]}$ of $F$. grandifolia was performed on Camag Linomat 5 instrument. Initially, F. grandifolia was dissolved in ethyl acetate $(10 \mathrm{mg} / 0.5 \mathrm{ml}$, HPLC grade), which was centrifuged at $3000 \mathrm{rpm}$ for $5 \mathrm{~min}$ and used for analysis. Sample $(0.2 \mu 1)$ was loaded as $6 \mathrm{~mm}$ band at length on $10 \times 10 \mathrm{~cm}$ HPTLC silica gel plate 60 F 254 using Hamilton syringe ( $100 \mu 1$ size). The loaded plate was placed in a thin-layer chromatography twin trough developing chamber and the plate was developed up to $70 \mathrm{~mm}$ in hexane:ethyl acetate (1:4) solvent system. The developed plate was dried and sprayed with stannic chloride reagent and placed in a Camag TLC Scanner to capture images at $254 \mathrm{~nm}$ using a UV lamp (D2 and W). Finally, the peak display along with peak tables, was identified and measured.

\section{Total flavonoid content:}

The total flavonoid content ${ }^{[22]}$ of the extracts was determined using aluminium chloride spectrophotometric method, in which $\mathrm{AlCl}_{3}$ forms a complex with hydroxyl groups of flavonoids in the test sample. To the extract $(1 \mathrm{mg} / \mathrm{ml})$ or standard quercetin solution $(3.125,6.25,12.5,25,50,100 \mu \mathrm{g} / \mathrm{ml}) 3 \mathrm{ml}$ of methanol, $1 \mathrm{ml}$ of $2 \% \mathrm{AlCl}_{3}$ solution, $200 \mu \mathrm{l}$ of $1 \mathrm{M}$ potassium acetate was added and the volume was made up to $10 \mathrm{ml}$ with distilled water and incubated for $60 \mathrm{~min}$ at room temperature. The blank contained only reagents, and the absorbance was read at $415 \mathrm{~nm}$. Based on the measured absorbance of the test sample, the total flavonoid content was determined from the calibration graph and the total flavonoid content was expressed in terms of quercetin equivalents (mg quercetin/g of extract).

\section{Total phenolic content:}

The total phenolic content ${ }^{[23-25]}$ was estimated by 
Folin-Ciocalteu's method. To the extract $(1 \mathrm{mg} / \mathrm{ml})$ or standard gallic acid solution $(3.125,6.25,12.5,25,50$, $100 \mu \mathrm{g} / \mathrm{ml}) 0.5 \mathrm{ml}$ of Folin-Ciocalteau reagent, $1.5 \mathrm{ml}$ of $20 \%$ sodium carbonate was added, the volume was made up to $10 \mathrm{ml}$ with distilled water and incubated at room temperature for $120 \mathrm{~min}$ and the absorbance was measured at $750 \mathrm{~nm}$ on a spectrophotometer against blank. Based on the measured absorbance of the test sample, the total phenolic content was read on the calibration graph and the total phenolic content was expressed in terms of gallic acid equivalent ( $\mathrm{mg}$ of gallic acid/g of extract).

\section{In vitro antioxidant activity, DPPH assay:}

F. grandifolia extract was subjected to the DPPH assay $^{[26]}$ in triplicate and results were reported as \% inhibition of DPPH free radical. Initially to known concentrations of the sample, $0.004 \% \mathrm{DPPH}$ dissolved in methanol was added and incubated for $30 \mathrm{~min}$ at $37^{\circ}$. Sample absorbance was read $517 \mathrm{~nm}$ against a suitable blank on a UV/Vis spectrophotometer (Spectra MAX plus 384, USA) Plotting concentrations against the \% inhibition determined IC50 values of $F$. grandifolia extract.

\section{Superoxide radical scavenging assay:}

F. grandifolia extract was screened in the superoxide radical scavenging assay ${ }^{[27]}$ in triplicate and results were expressed as \% inhibition of superoxide free radicals. NADH $(73 \mu \mathrm{M}), 15 \mu \mathrm{M}$ of PMS and NBT $(50 \mu \mathrm{M})$ in $20 \mathrm{mM}$ phosphate buffer (pH 7.4) was mixed and standardized. Then I ml of know concentrations of test sample was added to the above-standardized mixture and incubated for $30 \mathrm{~min}$. After incubation, absorbance of all the samples were read at $562 \mathrm{~nm}$ against blank. $\mathrm{IC}_{50}$ values of $F$. grandifolia extract were determined by plotting concentrations against $\%$ inhibition.

\section{Ferric ion $\left(\mathrm{Fe}^{3+}\right)$ reducing power assay:}

F. grandifolia extract was screened in the ferric ion $\left(\mathrm{Fe}^{3+}\right)$ reducing power assay ${ }^{[28]}$ in triplicate and results were expressed as $\%$ of inhibition of $\mathrm{Fe}^{3+}$ ions. To $2.5 \mathrm{ml}$ of phosphate buffer $(\mathrm{pH} 6.6,0.2 \mathrm{M}), 2.5 \mathrm{ml}$ potassium ferricyanide $(1 \%)$ and know concentrations of sample were added and incubated for $20 \mathrm{~min}$. Later, $2.5 \mathrm{ml}$ of $10 \%$ trichloroacetic acid and $0.5 \mathrm{ml}$ of $0.1 \%$ ferric chloride was added to each sample and the absorbance was read at $700 \mathrm{~nm}$ against a blank. $\mathrm{IC}_{50}$ values of $F$. grandifolia were determined by plotting concentrations against \% inhibition. Percent inhibition was calculated using the formula, $(\mathrm{C}-\mathrm{S}) / \mathrm{C} \times 100$, where
$\mathrm{C}$ is the absorbance of the control, $\mathrm{S}$ is the absorbance of sample.

\section{In vitro antidiabetic activity:}

The assay of $\alpha$-glucosidase inhibitory activity ${ }^{[2]}$ was performed in a triplicate. A stock solution of $\alpha$-glucosidase acetone powder from rat intestine acetone powder was made prepared $(1.0 \mathrm{mg} / \mathrm{ml}$ in $10 \mathrm{mM}$ phosphate buffer, $\mathrm{pH} 6.8$, diluted 40 -fold with the same buffer) and $2.0 \mu 1$ of this solution was mixed with $20 \mu \mathrm{l}$ of the samples of different concentrations (25, 50, 75 and $100 \mu \mathrm{g} / \mathrm{ml}$ dissolved in DMSO) and $100 \mu \mathrm{l}$ of $50 \mathrm{mM}$ phosphate buffer $(\mathrm{pH} \mathrm{6.8)}$ in 96 well microplates and incubated for $5 \mathrm{~min}$ at $37^{\circ}$. After incubation, $50 \mu \mathrm{l}$ of the substrate $(5 \mathrm{mM}$ of $p$-nitrophenyl- $\alpha$-D-glucopyranoside prepared in $50 \mathrm{mM}$ of phosphate buffer, $\mathrm{pH} 6.8$ ) was added and the entire reaction mixture was again incubated for $20 \mathrm{~min}$ at $37^{\circ}$. After that, the reaction was terminated by adding $50 \mu 1$ of $\mathrm{Na}_{2} \mathrm{CO}_{3}(1 \mathrm{M})$ and the final volume was made to $150 \mu \mathrm{l}$. The amount of $p$-nitrophenol released from the substrate was noted at $405 \mathrm{~nm}$ spectrophotometrically. DMSO and glibenclamide were used as control and standard, respectively. Percent inhibition of $\alpha$-glucosidase enzyme was calculated using the formula, $\%$ inhibition $=(\mathrm{C}-\mathrm{S}) / \mathrm{C} \times 100$, where $\mathrm{C}$ is the absorbance of the control, $\mathrm{S}$ is the absorbance of sample

The porcine pancreatic $\alpha$-amylase inhibitory assay[26] was determined in a triplet $(n=3)$. Amylase HR reagent $(100 \mu 1)$ and $40 \mu 1$ of sample of various concentrations $(50,100,150$ and $200 \mu \mathrm{g} / \mathrm{ml}$ of extract) were mixed and incubated for $10 \mathrm{~min}$ at $37^{\circ}$. Then $60 \mu \mathrm{l}$ of $0.1 \mathrm{mg} / \mathrm{ml}$ BPNPG7 (blocked $p$-nitrophenylmaltoheptaoside) in 0.1 M 4-(2-hydroxyethyl)-1-piperazineethanesulfonic acid buffer $\mathrm{pH} 6.9$ was added and further incubated for $10 \mathrm{~min}$ at $37^{\circ}$. The quantity of p-nitrophenol released from $p$-nitrophenyl- $\alpha$-D-glucopyranoside (substrate) was measured at $405 \mathrm{~nm}$ on a UV/Vis spectrophotometer (Electron 420 series spectrophotometer). DMSO was used as control and glibenclamide as a standard. $\mathrm{IC}_{50}$ values of test samples were determined by plotting concentrations of the sample against \% inhibition. The $\%$ inhibition of $\alpha$-amylase activity was calculated using the formula, $\%$ inhibition $=(\mathrm{C}-\mathrm{S}) / \mathrm{C} \times 100$, where $\mathrm{C}$ is the absorbance of the control, $\mathrm{S}$ is the absorbance of sample.

\section{RESULTS AND DISCUSSION}

Phytochemical analysis ${ }^{[20]}$ of $F$. grandifolia showed 
presence of different phytochemical constituents (Table 1), such as carbohydrates, flavonoids, phenolics, steroids, and tannins, but it gave negative results for alkaloids, carbohydrates, saponins, and glycosides. The HPTLC analysis ${ }^{[21]}$ gave the fingerprinting profile of $F$. grandifolia extract, which was illustrated in fig. 1. From the HPTLC chromatogram, 3 unknown compounds represented by peak 1,2 and 3 with $R_{f}$ values and percent areas of $-0.04,-0.01$ and 0.37 , and $16.67,54.43$ and $28.82 \%$, respectively (fig. 1).

Total flavonoid content ${ }^{[22]}$ and phenolic content ${ }^{[23]}$

TABLE 1: PHYTOCHEMICALS IN ETHANOL EXTRACT OF FISSIDENS GRANDIFOLIA

\begin{tabular}{lc}
\hline Phytochemical & Ethanol extract $F$. grandifolia \\
\hline Steroids & + \\
Saponins & - \\
Alkaloids & - \\
Carbohydrates & + \\
Flavanoids & + \\
Tannins & + \\
Glycosides & - \\
Phenolics & + \\
\hline
\end{tabular}

'+' indicates presence; '-' indicates absence expressed as quercetin equivalent and gallic acid equivalent, respectively, arrived at from the standard calibration line Eqns. $y=0.0096 x+0.0052 ; R^{2}=0.999$ and $\mathrm{y}=0.0038 \mathrm{x}+0.003 ; \mathrm{R}^{2}=0.9997$, respectively (fig. 2). F. grandifolia extract contained higher total flavonoid content $(101.40 \pm 0.38 \mathrm{mg} \mathrm{Q} / \mathrm{g})$ compared to total phenolic content $(65.71 \pm 0.95 \mathrm{mg} \mathrm{GA} / \mathrm{g})$ as shown in Table 2.

Among the phytochemicals from natural sources, polyphenols and flavonoids are usually regarded as the substances with high antioxidant capability. These compounds also reported to be effective against Alzheimer's, diabetes, eye disorders, cancer, and heart problems. Additionally, the most vital feature of phenolic and flavonoids is their ability to be effective against oxidative diseases like diabetes by reducing LDL oxidation $^{[24,25]}$.

In general, natural antioxidants have pronounced safety to mankind and are without any significant side effects. Based on the aforementioned points, F. grandifolia extract was screened initially against $\mathrm{DPPH}^{[26]}$,

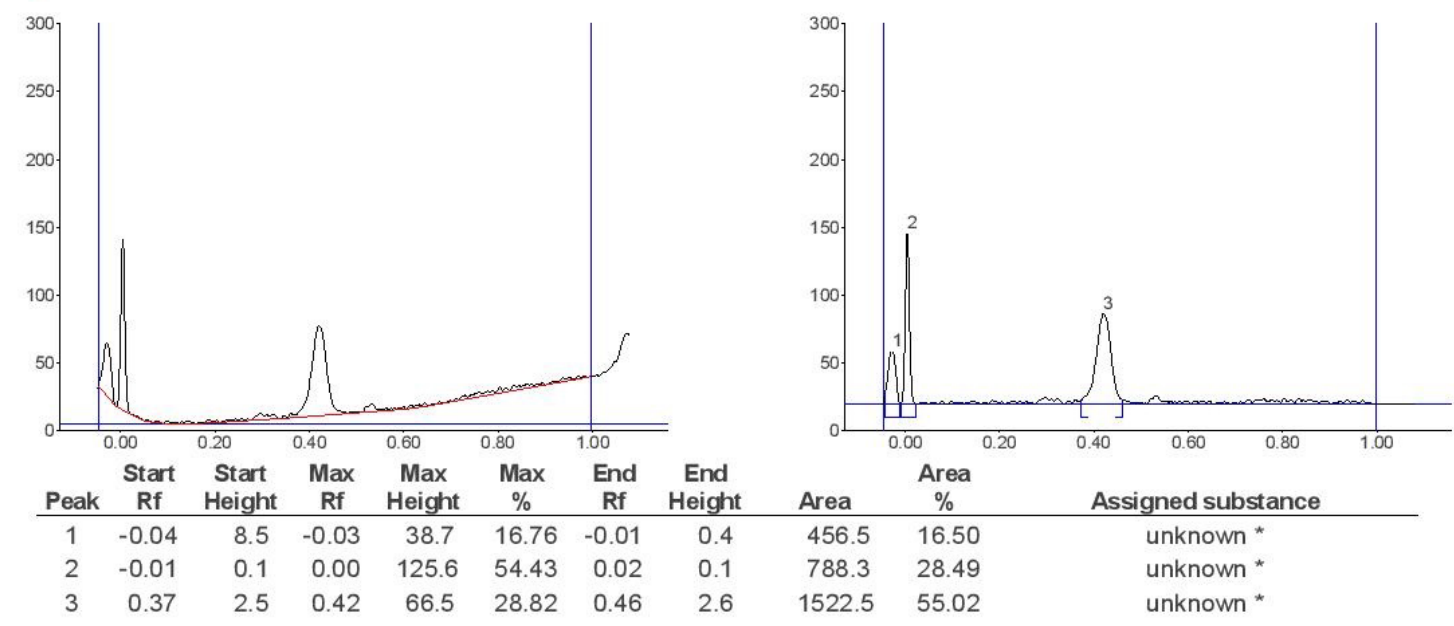

Fig. 1: HPTLC chromatogram of ethanol extract of $F$. grandifolia
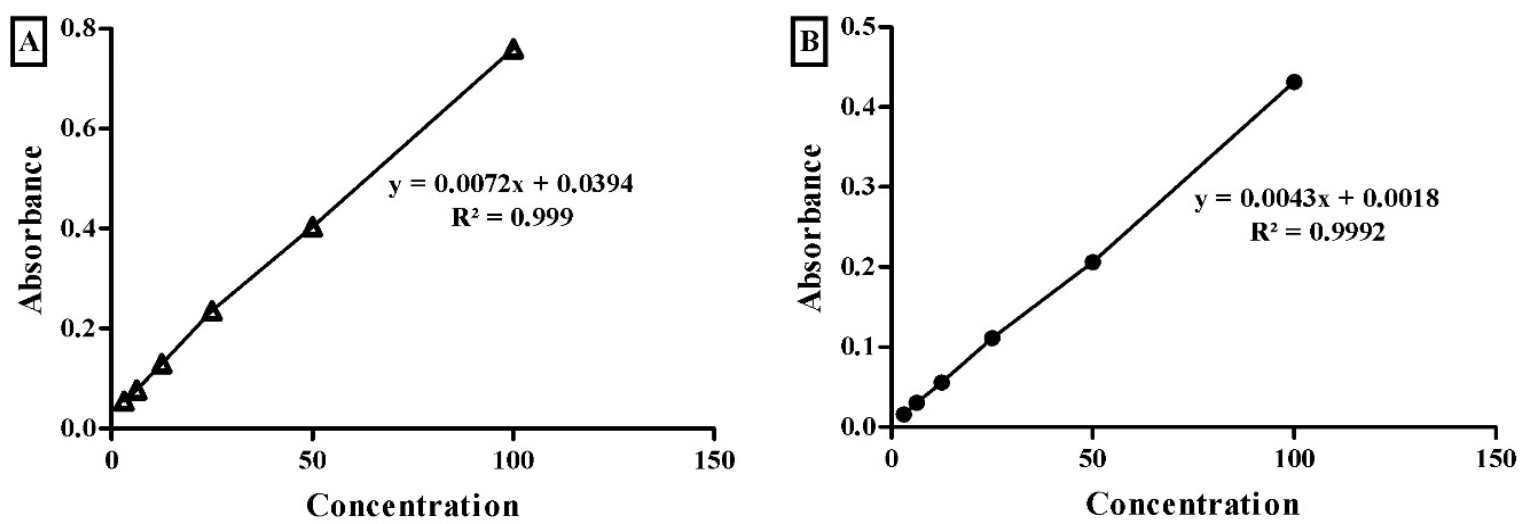

Fig. 2: Calibration graphs of ethanol extract of $F$. grandifolia Calibration graph for A. total flavonoid and B. phenolic contents of ethanol extract of $F$. grandifolia 
superoxide ${ }^{[27]}$, and ferric ion assays ${ }^{[28]}$, the results of which were illustrated in fig. 3 . The lower $\mathrm{IC}_{50}$ values indicate higher inhibition of free radicals. The principal of DPPH radical assay in which decoy of the DPPH radical to a non-radical form (DPPH-H) takes place. The $\mathrm{IC}_{50}$ values of $F$. grandifolia extract against DPPH was found to be $85.0 \mu \mathrm{g} / \mathrm{ml}$, whereas ascorbic acid's value was $29.5 \mu \mathrm{g} / \mathrm{ml}$.

On the other hand, the superoxide radicals arise from metabolic process interact with other substrates in presence of enzyme or metal catalysed routes to engender hydroxyl radical, peroxides and oxygen free radicals. These free radicals induce oxidative damage to lipids, DNA and proteins ${ }^{[25]}$. The concentration of $F$. grandifolia extract needed to cause $50 \%$ inhibition of superoxide radical was $81.0 \mu \mathrm{g} / \mathrm{ml}$, while ascorbic acid was $26.5 \mu \mathrm{g} / \mathrm{ml}$. The $\mathrm{IC}_{50}$ value of $F$. grandifolia

TABLE 2: TOTAL FLAVONOID AND PHENOLIC CONTENT OF FISSIDENS GRANDIFOLIA

\begin{tabular}{lcc}
\hline Sample & $\begin{array}{c}\text { Total flavonoid } \\
\text { content* }\end{array}$ & $\begin{array}{c}\text { Total phenolic } \\
\text { content* }\end{array}$ \\
\hline $\begin{array}{l}\text { Fissidens } \\
\text { grandifolia }\end{array}$ & $101.40 \pm 0.38 \mathrm{mg} \mathrm{Q} / \mathrm{g}$ & $65.71 \pm 0.95 \mathrm{mg} \mathrm{GA} / \mathrm{g}$ \\
\hline${ }^{*} \mathrm{n}=3 ;$ mean $\pm \mathrm{SD}$ & &
\end{tabular}

extract was $92.6 \mu \mathrm{g} / \mathrm{ml}$, whereas ascorbic acid value was $34.5 \mu \mathrm{g} / \mathrm{ml}$ (fig. 3). From all the antiradical assays, it can be concluded that $F$. grandifolia is preferably acting by exhibiting radical scavenging properties rather than reducing antioxidant power.

Natural sources with a high amount of phenolics and flavonoids, which display effective antioxidant profile have been recommended for use in the treatment of diabetes $^{[26]}$. Generally, the main biological target in diabetes of phenolics and flavonoids are $\alpha$-glycosidase and DPP-4, by acting as radical scavengers ${ }^{[29]}$. Therefore, as $F$. grandifolia revealed good phenolic and flavonoid content with prominent antioxidant activity, the study was extended to evaluate its ability to manage diabetes.

The $\alpha$-glucosidase inhibitory assay ${ }^{[22]}$ was performed using $p$-nitrophenyl- $\alpha$-D-glucopyranoside as a substrate and glibenclamide as a standard inhibitor. From the assay, it was estimated that the $\mathrm{IC}_{50}$ concentration needed for $F$. grandifolia to inhibit $\alpha$-glucosidase enzyme was $150.0 \mu \mathrm{g} / \mathrm{ml}$, while glibenclamide's was $29.3 \mu \mathrm{g} / \mathrm{ml}$ (fig. 4). The porcine pancreatic $\alpha$-amylase inhibition assay ${ }^{[2]}$ was performed using BPNPG7 and
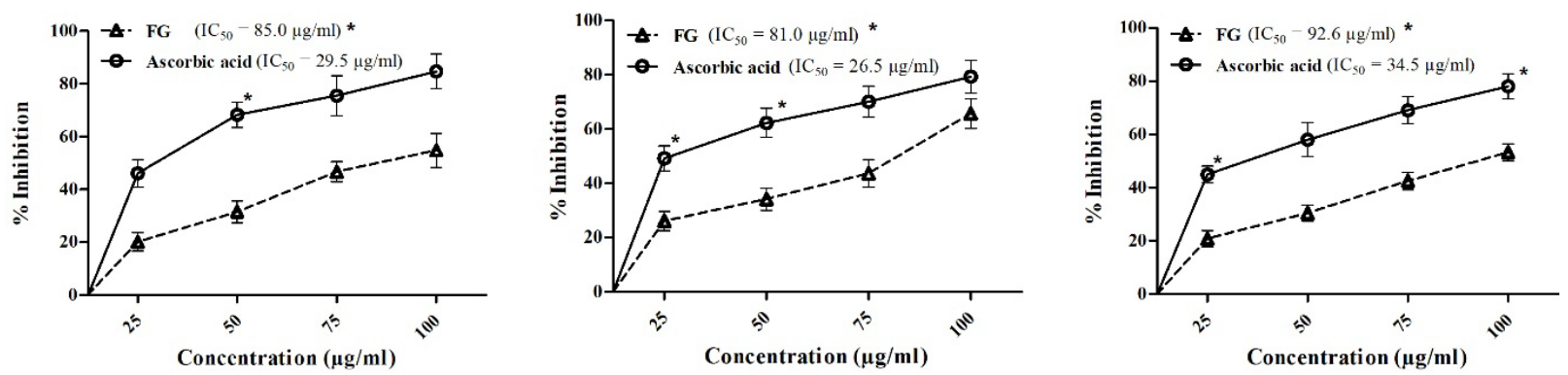

Fig. 3: Antioxidant activity profiles of ethanol extract of $F$. grandifolia

$I_{50}$ value determination of ethanol extract of $F$. grandifolia $(F G)$ against A. DPPH, B. superoxide and C. ferric ions, $n=3$; Mean \pm SD; *statistically significant at $\mathbf{p}<\mathbf{0 . 0 5}$. ( $-\circ)$ ascorbic acid
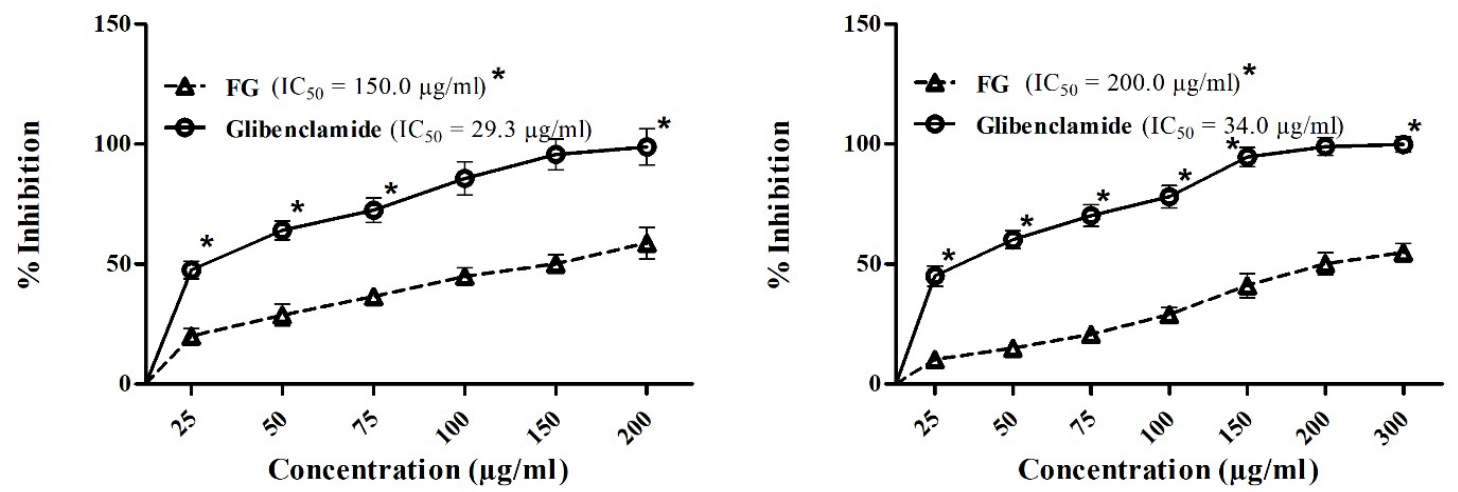

Fig. 4: $\alpha$-Glucosidase and $\alpha$-amylase inhibitory activity of ethanol extract of $F$. grandifolia

$\mathrm{IC}_{50}$ value determination of ethanol extract of $\boldsymbol{F}$. grandifolia against A. $\alpha$-glucosidase and $\mathrm{B}$. $\alpha$-amylase $\mathrm{n}=3$; mean $\pm \mathrm{SD}$; **statistically significant at $\mathbf{p}<\mathbf{0 . 0 5}$. ( - - glibenclamide 
glibenclamide as substrate and standard, respectively. The concentration of $F$. grandifolia extract needed to cause $50 \%$ inhibition of porcine pancreatic $\alpha$-amylase was found to be $200.0 \mu \mathrm{g} / \mathrm{ml}$, while glibenclamide was $34.0 \mu \mathrm{g} / \mathrm{ml}$ (fig. 4). From the outcomes of in vitro assays, it could be confirmed that the $F$. grandifolia extract could be antidiabetic by virtue of inhibiting digestive enzymes.

Diabetes mellitus is a metabolic disorder well-defined by hyperglycaemia resulting due to alteration in the metabolic rate of carbohydrate, lipid and proteins. Additionally, oxidative stress conditions assumed to augment free radical production. According to recent studies, the oxidative stress-induced free radicals have been associated in the pathology of diabetes mellitus ${ }^{[25-27]}$.

In the current study, phytochemical analysis of F. grandifolia revealed different phytochemical constituents (Table 1). The F. grandifolia was subjected to HPTLC analysis in order to develop the finger-print profile (fig. 1). Based on the phytochemical analysis data, the total flavonoid and phenolic contents of $F$. grandifolia were determined which revealed their presence in significant amounts (Table 2). Further, the antioxidant (DPPH and superoxide assays) activity, in vitro antidiabetic activity of $F$. grandifolia extract was evaluated and quantified to identify the extracts higher scavenging capacity towards DPPH and superoxide free radicals (fig. 3), which revealed that the antioxidant capability of $F$. grandifolia is due to freeradical quenching mechanism.

In addition, the outcomes of in vitro bioassays on digestive enzymes revealed that the $F$. grandifolia was specific towards $\alpha$-glucosidase enzyme and $\alpha$-amylase, which indicated the proposed mechanism of action of $F$. grandifolia might be acting by inhibiting particularly digestive enzymes like $\alpha$-glucosidase enzyme and $\alpha$-amylase (fig. 4).

In conclusion, present study provided primary information on the chemical composition, antioxidant, $\alpha$-glucosidase and $\alpha$-amylase inhibitory properties of $F$. grandiflora. The examination of the $F$. grandifolia revealed the existence high flavonoid content. The main substances identified from phytochemical analysis of F. grandifolia were carbohydrates, steroids, polyhydroxy compounds and aliphatic fatty acids. Additionally, evaluation of antioxidant and antidiabetic activities suggested that $F$. grandifolia possessed DPPH and superoxide free radical suppressing property and $\alpha$-glucosidase and porcine pancreatic $\alpha$-amylase inhibitory activity. This information provided some evidence to the traditional medical application of F. grandiflora to manage diabetes. These active constituents needs to be isolated and further investigated to find out how $F$. grandiflora reduced free radicals in diabetes.

\section{Conflict of interest:}

No conflict of interest between any of the authors.

\section{REFERENCES}

1. Wang XN, Yu WT, Lou HX. Antifungal constituents from the Chinese moss Homalia trichomanoides. Chem Biodiver 2005;2:139-45.

2. Peters K, Gorzolka K, Bruelheide H, Neumann S. Seasonal variation of secondary metabolites in nine different bryophytes. Ecol Evol 2018;8:9105-17.

3. Sastry GV, Bharadwaj VT. Occurrences of mosses in Indian mangrove forests. Integr Sci 2018;1:1-6.

4. Schofield WB. Bryophyte disjunctions in the northern hemisphere: Europe and North America. Bot J Linn Soc 1988;98:211-24.

5. Singh M, Govindarajan R, Nath V, Rawat AK, Mehrotra S. Antimicrobial, wound healing and antioxidant activity of Plagiochasma appendiculatum Lehm. et Lind. J Ethnopharmacol 2006;107:67-72.

6. Sabovljević A, Soković M, Glamočlija J, Ćirić A, Vujičić M, Pejin B, et al. Comparison of extract bio-activities of in-situ and in-vitro grown selected bryophyte species. Afr J Microbiol Res 2010;4:808-12.

7. Puri B, Hall A. Phytochemical dictionary: a handbook of bioactive compounds from plants. CRC press: Boca Raton, Florida, United States; 1998.

8. Melo IS, Santos SN, Rosa LH, Parma MM, Silva LJ, Queiroz $\mathrm{SC}$, Pellizari VH. Isolation and biological activities of an endophytic Mortierella alpina strain from the Antarctic moss Schistidium antarctici. Extremophiles 2014;18:15-23.

9. Cheng X, Xiao Y, Wang X, Wang P, Li H, Yan H, et al. Antitumor and pro-apoptotic activity of ethanolic extract and its various fractions from Polytrichum commune L. ex Hedw in L1210 cells. J Ethnopharmacol 2012;143:49-56.

10. Suire C, Bourgeois G, Koponen T. Some chemical constituents of thirteen mosses from the traditional Mniaceae family. J Hattori Bot Lab 2000;89:233-46.

11. Naidu KK, Priya SSA, Bharadwaj VT. In vitro antiinflammatory and anticancer activities of Octoblepharum albidum Hedw. Am J Med Nat Sci 2020;1:19-24.

12. Üçüncü $\mathrm{O}$, Cansu Tb, Özdemir $T$, Karaoğlu Şa, Yayli N. Chemical composition and antimicrobial activity of the essential oils of mosses (Tortula muralis Hedw., Homalothecium lutescens (Hedw.) H. Rob., Hypnum cupressiforme Hedw., and Pohlia nutans (Hedw.) Lindb.) from Turkey. Turk J Chem 2010;34:825-34.

13. Savaroğlu F, İşçen Cf, Vatan Ap, Kabadere S, Ilhan S, Uyar R. Determination of antimicrobial and antiproliferative activities of the aquatic moss Fontinalis antipyretica Hedw. Turk J Biol 2011;35:361-9.

14. Tatipamula VB, Vedula GS. Anti-inflammatory properties of Dirinaria consimilis extracts in albino rats. J Biomed Sci 2017;4:3-8. 
15. Ilhan S, Savaroğlu F, Çolak F, Işçen CF, Erdemgil FZ. Antimicrobial activity of Palustriella commutata (Hedw.) ochyra extracts (Bryophyta). Turk J Biol 2006;30:149-52.

16. Pejin B, Bogdanović-Pristov J. ABTS cation scavenging activity and total phenolic content of three moss species. Hem Ind 2012;66:723-6.

17. Krzaczkowski L, Wright M, Rebérioux D, Massiot G, Etiévant C, Gairin JE. Pharmacological screening of bryophyte extracts that inhibit growth and induce abnormal phenotypes in human HeLa cancer cells. Fundam Clin Pharmacol 2009;23:473-82.

18. Tatipamula VB, Killari KN, Ketha A, Sastry VG. Taxithelium napalense acts against free radicals and diabetes mellitus. Bangladesh J Pharmacol 2017;12:197-203.

19. Crosby MR, Magill RE, Allen B, He S. A checklist of the mosses. St. Louis: Missouri Botanical Garden; 2000.

20. Talluri MR, Ketha A, Battu GR, Tadi RS, Tatipamula VB. Protective effect of Aurelia aurita against free radicals and streptozotocin-induced diabetes. Bangladesh J Pharmacol 2018;13:287-95.

21. Deattu N, Suseela L, Narayanan N. Chromatographic analysis of polyherbal extract and formulation by HPTLC and GC-MS methods. J Pharm Res 2013;6:6-10.

22. Tatipamula V, Killari K, Gopaiah K, Ketha A. GC-MS Analysis of Ethanol Extract of Taxithelium napalense (Schwaerg) Broth along with its $\alpha$-Glucosidase Inhibitory Activity. Indian J Pharm Sci 2019;81:569-74.

23. Tatipamula VB, Vedula GS, Rathod BB, Shetty PR, Sastry AV.
Study of phytochemical analysis, total flavonoid and phenolic content, antimicrobial properties and chemical constituents of two manglicolous lichens extracts. Inventi Rapid: Planta Activa 2018;2018:129-34.

24. Huyut Z, Beydemir Ş, Gülçin İ. Antioxidant and antiradical properties of selected flavonoids and phenolic compounds. Biochem Res Int 2017;1-10.

25. Tatipamula VB, Annam SS, Nguyen HT, Polimati H, Yejella RP. Sekikaic acid modulates pancreatic $\beta$-cells in streptozotocininduced type 2 diabetic rats by inhibiting digestive enzymes. Nat Prod Res 2020:1;5.

26. Tatipamula VB, Polimati H, Rao GK, Ketha A, Yejella RP. Isolation and Characterization of metabolites from Clathria procera Ridley extract and Evaluation of its antidiabetic effects in streptozotocin-induced diabetic rats. J Exp Appl Animal Sci 2019;3:35-56.

27. Tatipamula VB, Kolli MK, Lagu SB, Paidi KR, Reddy $\mathrm{R}$, Yejella RP. Novel indolizine derivatives lowers blood glucose levels in Streptozotocin-induced diabetic rats: A histopathological approach. Pharmacol Rep 2019;71:233-42.

28. Haritha P, Patnaik SK, Tatipamula VB. Chemical and pharmacological evaluation of manglicolous lichen Graphis ajarekarii Patw. \& CR Kulk. Vietnam J Sci Technol 2019;57:300-8.

29. Tatipamula VB, Kukavica B. Protective effects of extracts of lichen Dirinaria consimilis (Stirton) DD Awasthi in bifenthrinand diazinon-induced oxidative stress in rat erythrocytes in vitro. Drug Chem Toxicol 2020:1;8. 